\title{
'OLD-NEW' MINING TOWNS - EXAMPLES OF THE RENOVATION AND ADAPTATION OF POST-INDUSTRIAL OBJECTS
}

\author{
Piotr LANGER ${ }^{1}$ \\ Cracow University of Technology, Cracow, Poland
}

\begin{abstract}
Poland's economic transformation has proved to be a critical phase in the contemporary development of its industrial cities, initiating profound spatial and functional changes. In researching the basics of the development of 'post-industrial' cities, it can be seen that the work undertaken is focused on reusing post-industrial buildings and objects. This results not only in functional changes in the appearance and condition of the transformed structures, but also preserves or destroys their authenticity and historical identity. This problem is linked with several phenomena, including 'aware inactivity', 'destructive adaptation', and 'false revitalization'.
\end{abstract}

Keywords: mining, post-industrial areas and objects, revitalization, urban space, identity, adaptation, renovation.

\section{INTRODUCTION}

Following the political transformation of Poland in the early 1990s, changes in the country can be seen to have accelerated, particularly in the last decade. The continuous socio-economic transformation process is undoubtedly at the root of these changes, as well as globalization and industry's reorientation from traditional production means toward new technologies, searching for innovations and better implementation of information and knowledge.

\footnotetext{
${ }^{1}$ Corresponding author: Cracow University of Technology, Faculty of Architecture, Warszawska st 24, 31-155 Kraków, Poland, e-mail: piotrlanger@ pro.onet.pl, tel. +48126282050
} 
The entire social and political transformation process had a major impact on the urban space of most cities in Poland - regardless of their size, location, history or financial condition. Transformation of urban areas has included both downtown and peripheral suburban areas considered as requiring intervention in multiple areas.

These processes are clearly highlighted in areas dominated by industrial functions, particularly in the actual industrial centres, which were affected by the economic transformation in a special way.

The past few decades, especially the 1990s, can be regarded as landmark in the history of these cities. Because of the extensive restructuring of key industries, the cities related to them, that had flourished under the centrally controlled economy, lost their previously solid footing and were forced to map out a new vision for their own development in an age of free markets and competition.

As a result of the move away from traditional means of production, a new emphasis on implementing new technologies, the search for cheaper labour markets and the resulting changes in ownership structures, many industrial plants drastically reduced or completely ceased operation, becoming problematic areas in their urban space. And because of the conflicts and disturbances generated, buildings and brownfields areas are also a major factor in the specificity and identity of the urban environment. Still, they are an important and authentic part of the cultural heritage, as they are home to urban elements that are not only strictly industrial, but also have related functions, such as administrative, residential (worker housing), economic and storage, as well as purely technical, engineering structures and open spaces of different purposes.

The potential and importance of any industrial heritage is a specific part of the structure of cities. On one hand, closed factories are often located near urban centres and major arterial roads, but are usually fully equipped with machinery and technical infrastructure. This translates as high availability and economic value. At the same time, many industrial facilities come from a long tradition, representing significant historical, architectural and urban planning values that play an important role in shaping the composition of the urban space. They are often an important part of the local cultural landscape, especially in terms of public perception.

It can therefore be assumed that abandoned elements of industrial heritage, despite their lack of usefulness, are attractive in terms of space and cost. This can be proved by the numerous redevelopment projects in post-industrial areas, 
undertaken both by local government and commercial entities ${ }^{2}$. These kinds of investments frequently assumed full or partial preservation of the existing structure, with adaptation to new functions, as well as changes in the development plan for their undeveloped open spaces.

Based on observation of the current condition and transformation processes of post-industrial elements in Polish cities, this article outlines the main courses of action taken and the negative phenomena accompanying them, which are here called 'deliberate inactivity, 'destructive adaptation' and 'false revitalization'. In order to explain these terms, an overall analysis of short-term and long-term effects posed by activities in post-industrial areas, or omission of such actions, has also been made.

In particular, attention is given to the relationship between the improvement of machinery and technical facilities, and their role in the buildings' authenticity and identity.

These issues are discussed using the examples of old underground mining operations. The validity of this choice is proved by the diversity and great adaptive potential of mining structures, as well as the relevance and importance of the issue - especially to the many mining towns in Poland, which have recently become the target of a wider revitalization process, prompted primarily by the number of closed underground mines.

\section{DELIBERATE INACTIVITY}

With the liquidation of an industrial plant, all technological processes are stopped. With underground mining operations, after the completion of their workings they are filled in, with few exceptions. The hoists, lift machinery and towers controlling vertical transportation in the shafts also cease. In the liquidation process the above-ground infrastructure of the mine loses therefore its current usefulness purpose.

The experience of Polish cities shows that a large proportion of post-mining objects gain no new users, and apart from temporary protection do not undergo further intervention. The reasons for this vary, but the main obstacle to the reuse of mining objects seems primarily to be the high cost of their cleaning, adaptation and modernization, as well as the unusual use of space and construction of industrial and mining buildings, thus making it harder to adapt

\footnotetext{
${ }^{2}$ The impetus being the not-insignificant financial aid obtainable from European Union programmes. A significant part of the funds obtained in this period were awarded to the reconstruction of degraded urban areas, including post-industrial - initially under Integrated Regional Operational Programme (2004-2006), and then the Regional Operational Programmes (2007-2013).
} 
them to other purposes. Another factor discouraging redevelopment of inactive mining facilities is the legal protection of historic buildings of significant architectural value. This is usually associated with the more or less stringent rules that exist on converting protected objects, covering, for example, the need to preserve or restore a characteristic detail, or to maintain the original architectural form and composition, and these stipulations can significantly limit the extent of permissible transformations and effectively discourage potential investors .

As regards mining buildings, one result of this 'deliberate inactivity' is their progressive deterioration, which in the long term leads to their complete degradation and a state in which functional adaptation and even maintenance become extremely difficult, or even impossible. The ultimate outcome is irrevocable elimination of the buildings, with demolition and clearing of nowuseless debris.

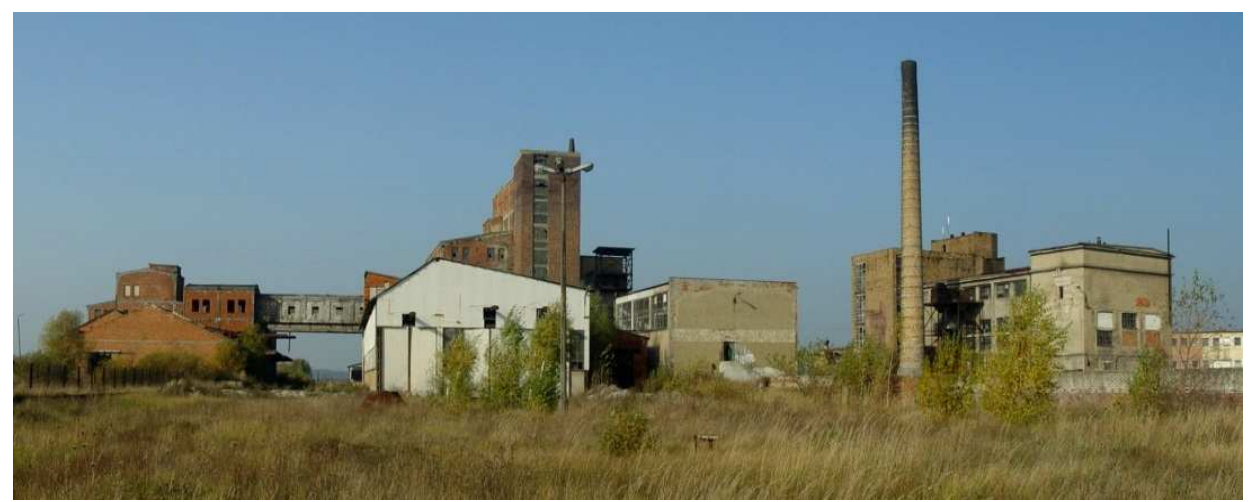

Fig. 1. The abandoned, mostly undeveloped building of the liquidated Salt Mine in Wapno. One of the deteriorating structures here houses a giant hoist, and is a protected building. (Photo: Author, 2007).

In addition to the numerous mines in Upper Silesia, examples of these kinds of facilities include The 'Wacław' historic coal mine and power plant in Ludwikowice Kłodzkie, in the Lower Silesian Coal Basin, as well as the remains of the Salt Mine in Wapno, in the Greater Poland Province, which was closed down in the 1970s (Fig. 1).

In some cases this 'deliberate inactivity' seems like purposeful self-destruction of former mining facilities - which are often considered 'unsightly' and useless - thus opening the way to free management of the released area, without having to consider any existing ruins or elements. 


\section{DESTRUCTIVE ADAPTATION}

In the process of liquidating industrial plants, including mining plants, fundamental changes are made in the ownership structure of their assets, including of preserved cubature objects. With a widespread lack of vision or ideas for the redevelopment of closed underground mines, their above-ground elements - often scattered around the urban space - change owners or administrators, and can be converted according to the individual needs of their new investors.

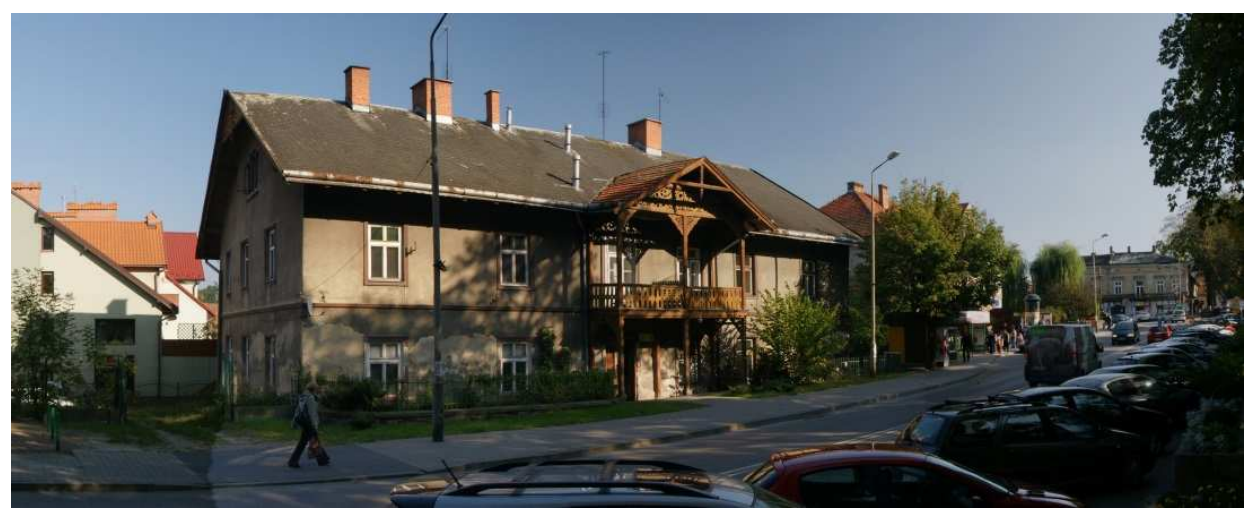

Fig. 2. The Saltworks Castle in Bochnia was built in the 19th century by the Austrian Mining Board, on the site of a medieval defensive structure (Photo: Author, 2010). In recent decades, the building had been used as a residence, but due to its catastrophic condition now, has been closed to further use, despite being a protected building.

Post-mining objects are often transferred to the local municipalities in which they operated. This applies primarily to individual buildings and residential complexes constructed for the miners and their families. In many cases, local authorities use these properties for their own needs, for example by allocating them as housing for low-income, disadvantaged or at-risk social groups. The immediate priorities in these cases may only lie in partial reconstruction, modernization or renovation to bring an initial improvement in their condition. Later, thus-adapted residential buildings experience further technical degradation, and in extreme cases fall into ruination and become unsuitable for further use. This can be seen in the Saltworks Castle in Bochnia (Fig. 2), which was turned into communal housing in the latter half of the 20th century.

The issues described don't only concern Polish cities. Similar phenomena, though on a smaller scale, can also be observed in other highly-developed European countries. One example is the historic mining district of Bois-du-Luc in Belgium, which is currently inhabited by various minority groups and in 
terms of its physical condition, differs significantly from the buildings in neighbouring areas.

The problem of 'destructive adaptation' also manifests itself in some forms of repurposing applied to old mining buildings, for commercial services, small craft production and associated supporting functions.

The assets of most liquidated mining facilities include large-scale objects, which are hired out for services or small-scale production activities, as well as for storage purposes. These functions usually do not require facilities of high technical quality - they can easily occupy spaces of a lower standard, the use of which only requires ongoing maintenance and safety measures, which also reduces the cost of the rental and maintenance (Fig. 3).

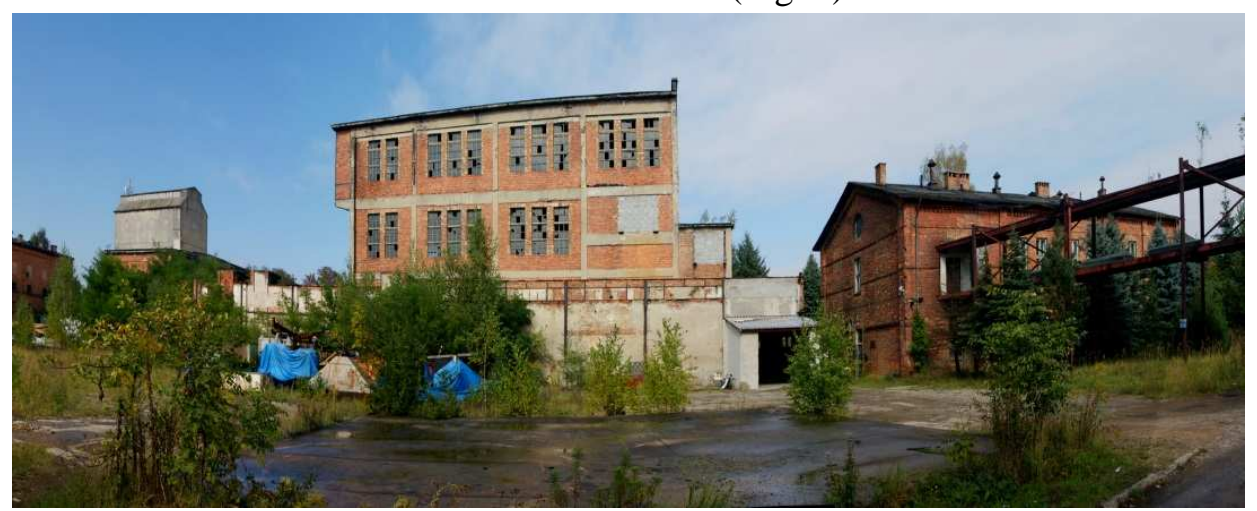

Fig. 3. The pit bank of the abandoned 'Matilda' zinc and lead mine in Chrzanów, now partly used for storage and craft activities (Photo: Author, 2012). Currently, the usage of many abandoned objects does not correspond with their architectural values and the landscape of their urban space. Similar phenomena can be observed in other postmining regions in Poland, such as the previously-mentioned Salt Mine in Wapno.

Temporary users of such buildings are only interested in maintaining the building on a certain - as low as possible - level. Their condition cannot be maintained like this indefinitely, and redeveloped post-mining structures require complete renovation anyway to make them suitable for further use. However, 'destructive adaptation' can not only worsen a structure's technical condition, but is also unhelpful in highlighting architectural and other features that contribute to the industrial character and identity of their mining towns.

\section{FALSE REVITALISATION}

Modern reconstruction and development of post-mining properties, especially the pit shaft assemblies in inactive underground mines, is usually conducted under the banner of 'revitalization', regardless of the scope and expected impact 
of the work. The main objective is to revitalize an abandoned or degraded area, which in the case of inactive mines can only be achieved by adapting them to new functions. This requires reconstruction, modernization and renovation of post-mining objects, and sometimes also their partial demolition.

However, in practice, the work can often be described as 'false revitalization' because it doesn't take into account the overriding need to preserve the original character of the buildings and structures. Although the effect is indeed of providing them with new uses, with an objective improvement in their technical condition, at the same time they lose their authenticity and atmosphere - their identity as inherent elements of traditional mining towns.

One determinant of this 'false revitalization' is, in many cases, the reasoning behind initiation of the process. The Polish experience shows that the main objective of such interventions, usually undertaken by private investors, (domestic and foreign), is for acquisition of attractive areas for large commercial projects, rather than a desire to preserve and protect cultural heritage.

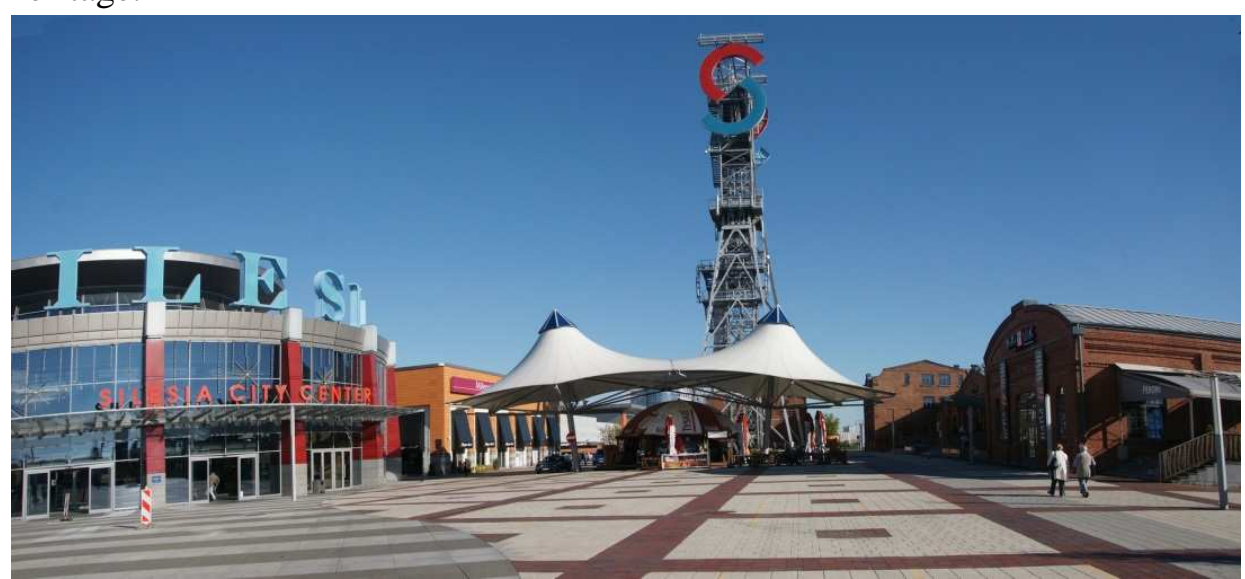

Fig. 4. The historic former 'Gottwald' coal mine in Katowice, 'revitalized' for the purpose of building a shopping centre (Photo: Author, 2012). One particularly glaring part of the new complex is the preserved shaft tower - the main signifier of mining towns, now used as an element of advertising.

As a result of 'false revitalization', brownfields no longer have such a significant role and have become subservient to the pursuit of the highest financial profits possible. This is understandable from the point of view of an investor, but results in decreased and often radical transformation of former mining resources, to the obvious detriment of the authentic character and attractiveness of their towns. 
Good examples of this phenomenon are some of the current 'revitalization' projects for Silesian mines, including the 'Gottwald' coal mine in Katowice (Fig. 4), and the recently completed reconstruction and adaptation of the 'Teresa' pit bank at the 'Thorez' coal mine in Wałbrzych (Fig. 5).

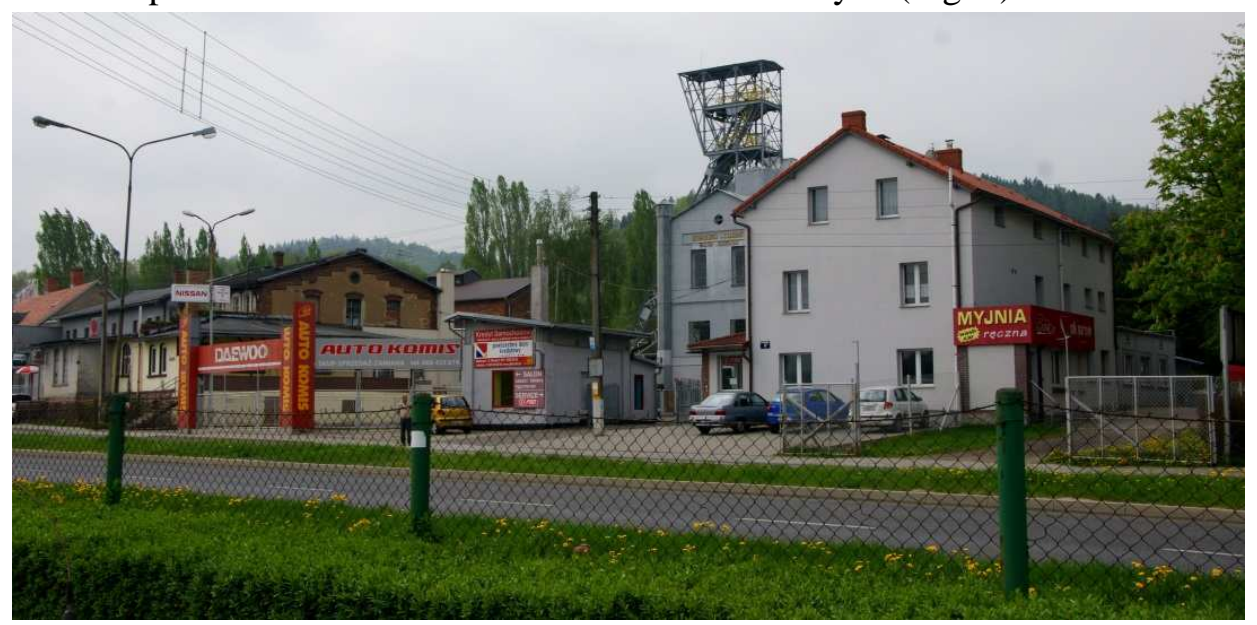

Fig. 5. The 'Teresa' pit bank of the closed 'Thorez' coal mine in Walbrzych, with its preserved extraction tower, was sold to a private investor and turned into a car service centre (Photo: Author, 2012). However, a positive aspect of this adaptation is the small museum of technology opened on the premises.

\section{SUMMARY AND CONCLUSIONS}

Based on the examples given in this article, an overall picture emerges of the current status and trends in industrial heritage, in the crucial period of transformation of 'old-new' mining towns. Approaches to liquidated but still extant underground mines vary, and are characterized by extreme attitudes from a lack of interest to a radical transformation, repurposing former mining facilities to new functions, including commercial ones.

In the course of the discussion three negative processes have been described, with their immediate and long-term effects. The author focused on the assessment of changes made in the condition and use of such facilities, and the impact of these changes on the authenticity - and thus the identity - of the urban space. These effects are summarised in Table 1 below. 
Table 1. Summary list of specific processes associated with preserved former mining facilities and their impact on the facilities' conditions, use and authenticity (Author's own work).

Table 1. Processes characterizing the transformation of preserved former-mining structures, and their impact on the urban space

\begin{tabular}{|c|c|c|c|c|}
\hline \multirow{3}{*}{ Process } & \multicolumn{4}{|c|}{ Process's effect on } \\
\hline & \multicolumn{2}{|c|}{ Objects' technical condition } & \multirow{2}{*}{$\begin{array}{l}\text { Use of the } \\
\text { facilities }\end{array}$} & \multirow{2}{*}{$\begin{array}{c}\text { Structures' } \\
\text { authenticity and the } \\
\text { identity of its urban } \\
\text { space }\end{array}$} \\
\hline & ad hoc & long term & & \\
\hline 'Deliberate inactivity' & $>$ & $\nabla$ & O & \multirow{3}{*}{$\square$} \\
\hline 'Destructive adaptation' & $\Delta$ & $\nabla$ & - & \\
\hline 'False revitalisation' & $\Delta$ & $\Delta$ & - & \\
\hline
\end{tabular}

Symbols:

A Improvement of the technical condition (renovation works)

- Maintenance of the technical condition (maintenance and protection of objects)

- Significant deterioration of the technical condition, often necessitating demolition (degradation)

- Lack of use (functional uselessness)

Use of the building until the total deterioration of its technical condition (temporary functional adaptation)

- Sustainable use of the object (functional adaptation)

Loss of authentic character, causing harm to the identity and attractiveness of the town/city

The data summarized in the table shows that the least desirable, but also the most frequently observed phenomenon, is 'conscious inactivity'. This leads not only to the complete elimination of abandoned mining structures, especially of old mine shaft buildings, but is also characterised by the functional uselessness of these objects throughout their post-industrial existence.

With regards to 'destructive adaptation', the temporary improvement of the condition of the structures being renovated for their subsequent repurposing can be observed, although the work done is generally of a bare-minimum standard, not compliant with the status of the structures. Inappropriate usage of postmining buildings results in their further deterioration, and in the long term negates the rationale for their further use.

The last of the three processes discussed - 'false revitalization', appears to be advantageous because it ensures the lasting improvement of the condition of the industrial buildings being 'revitalized', and gives them a new purpose. It should be noted, however, that from the point of view of the identity and attractiveness of the urban space, all three processes are negative, as each results in a 
permanent change of the original character of the cities, thus reducing their spatial qualities and threatening their identity. It can also be concluded that the renovation and functional adaptation of post-mining facilities should be considered harmful, if the work is designed and implemented without taking into account the specific nature of the structures' industrial heritage.

In the context of the issues presented here, it is worth looking at the models for revitalizing old underground mines adopted in Western Europe. A good example there is the abandoned 'Zollverein' coal mine in Essen, Germany, which shows that the essence of effective revitalization of brownfield complexes is to maintain and enhance their authenticity. This is reflected, for example, in maintenance of their original technical condition, while limiting their renovation and modernization to the minimum needed for their specific, new usage.

This observation leads to the conclusion that the renovation and subsequent usage of abandoned mining structures is just one of many activities undertaken in the name of the complex process of revitalization, which is no guarantee of effectiveness.

\section{"STARE-NOWE" MIASTA GÓRNICZE. RENOWACJA I ADAPTACJA OBIEKTÓW POPRZEMYSŁOWYCH NA WYBRANYCH PRZYKŁADACH}

\section{Streszczenie}

W poszukiwaniu podstaw rozwoju miast epoki ,postindustrialnej”, podejmuje się w szerokie spektrum działań ukierunkowanych na wykorzystanie elementów poprzemysłowych, czego skutkiem jest zmiana przeznaczenia, wyglądu i stanu obiektów, ale również wpływ na autentyczność i tożsamość miast. W artykule skupiono się na miastach górniczych, których dziedzictwo cechuje się dużym potencjałem adaptacyjnym, a często również unikatowymi wartościami. Analizując stan i przemiany elementów pogórniczych można stwierdzić, że wskazane problemy znacząco oddziałują na funkcję oraz formę tych elementów i w związku z tym mają duży wpływ na współczesną autentyczność i tożsamość całych miast. Wnioski płynące z rozważań mogą być przydatne $\mathrm{w}$ programowaniu i realizacji działań z zakresu przebudowy i adaptacji funkcjonalnej obiektów poprzemysłowych $\mathrm{w}$ miastach tradycyjnie związanych $\mathrm{z}$ górnictwem podziemnym, również na terenie Polski.

Słowa kluczowe: górnictwo, tereny i obiekty poprzemysłowe, rewitalizacja, przestrzeń miejska, tożsamość, adaptacja, renowacja. 